\title{
Architecture_MPS
}

\section{Gender, Public Space and Resistance}

Gülsüm Baydar ${ }^{1}$

How to cite: Baydar, G. 'Gender, Public Space and Resistance.' Architecture_MPS, 2014, 5(1): 3, pp. 1-12. DOI: https://doi.org/10.14324/111.444.amps.2014v5i3.001.

Published: 01 September 2014

\section{Peer Review:}

This article has been peer reviewed through the journal's standard Editorial double blind peer review.

\section{Copyright:}

(C) 2014, The Author(s). This is an Open Access article distributed under the terms of the Creative Commons Attribution License (CC-BY) $2.0 \mathrm{https}: / /$ creativecommons.org/licenses/by/2.0/, which permits re-use, distribution and reproduction in any medium, provided the original author and source are credited • DOI: https://doi.org/10.14324/111.444.amps.2014v5i3.001

\section{Open Access:}

Architecture_MPS is a peer-reviewed open access journal. 


\title{
Title: Gender, Public Space and Resistance
}

\author{
Gülsüm Baydar
}

\begin{abstract}
Architecture_media_politics_society. vol.5, no.3.
\end{abstract}
September 2014

Affiliation: Yaşar University, Izmir, Turkey

\begin{abstract}
:
On May 27, 2013 at 11:30 pm bulldozers drove into Gezi, a central park in Taksim, Istanbul, to uproot five trees in preparation for future construction. Plans for the redevelopment had been announced two years before by the Prime Minister, Recep Tayyip Erdoğan, and in response, two local activist groups had been formed: 'Taksim Solidarity' and the 'Society for the Preservation and Beautification of Gezi Park'. Founded to to publicise the historical status of the park and protect what remains a symbolically important site - and one of the few recreation areas in the central area of Istanbul - members of these groups were amongst the first to protest as the bulldozers rolled in. Within hours, a group of twenty to thirty activists had begun a sit-in.
\end{abstract}

In the coming days, as the number of demonstrators increased to hundreds, the 'resistance' spread to other neighbourhoods in Istanbul. It also manifest itself in other cities across the country. The small scale sit-in that commenced in the night of May 27th had become a catalyst for a nationwide movement with global repercussions. It subsequently became known, interchangeably, as the Gezi movement, the Gezi resistance and Gezi events. The space of the protests was no longer bounded by Gezi Park itself, and the movement was no longer limited to a specific and local planning agenda.

Taking criticism of the renovation plans for Taksim as their starting point, the protesters also raised their voices against what they considered the authoritarian policies of the the conservative government and, more specifically, the social pronouncements of the Prime Minister. The governmental response was violent police intervention. Within a month, five protesters and one policeman had died, hundreds of others were injured, and many protestors were arrested across the country. In the midst of what the government defined as anarchy and subversive acts, multiple social and cultural assumptions were overturned and, in Deleuze and Guattari's terms, events and behaviours were deterritiorialized. Transient actions in established spaces smoothed the striated spaces of government planning and, equally significantly, a radical and momentary reconceptualisation of gendered roles and spaces was established. 


\title{
Title: Gender, Public Space and Resistance
}

\author{
Authors: Gülsüm Baydar
}

Architecture_media_politics_society. vol. 5, no.3.

September 2014

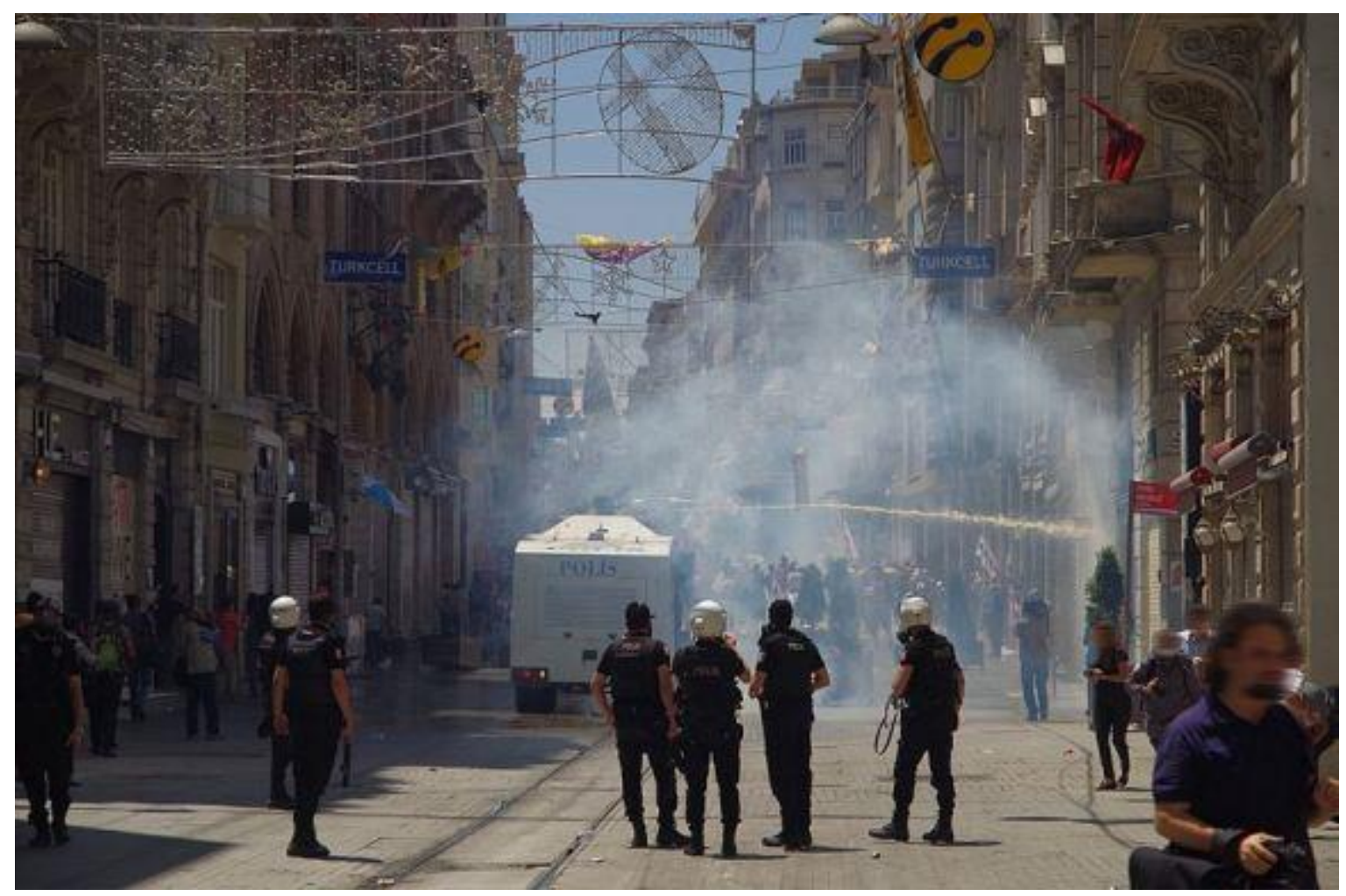

Alan Hilditch, TOMA Water Cannon \& Tear Gas used on İstiklâl Caddesi near Taksim Square

\section{Introduction:}

On May 27, 2013 at 11:30 pm bulldozers drove into Gezi, a central park in Taksim, Istanbul, to uproot five trees in preparation for future construction. Plans for the redevelopment had been announced two years before by the Prime Minister, Recep Tayyip Erdoğan, ${ }^{1}$ and in response, two local activist groups had been formed: 'Taksim Solidarity' and the 'Society for the Preservation and Beautification of Gezi Park'. Founded to to publicise the historical status of the park ${ }^{2}$ and protect what remains a symbolically important site - and one of the few recreation areas in the central area of Istanbul members of these groups were amongst the first to protest as the bulldozers rolled in. ${ }^{3}$ Within hours, a group of twenty to thirty activists had begun a sit-in.

In the coming days, as the number of demonstrators increased to hundreds, the 'resistance' spread to other neighbourhoods in Istanbul. It also manifest itself in other cities across the country. The small 
scale sit-in that commenced in the night of May 27th had become a catalyst for a nationwide movement with global repercussions. It subsequently became known, interchangeably, as the Gezi movement, the Gezi resistance and Gezi events. The space of the protests was no longer bounded by Gezi Park itself, and the movement was no longer limited to a specific and local planning agenda.

Taking criticism of the renovation plans for Taksim as their starting point, the protesters also raised their voices against what they considered the authoritarian policies of the the conservative government and, more specifically, the social pronouncements of the Prime Minister. The governmental response was violent police intervention. Within a month, five protesters and one policeman had died, hundreds of others were injured, and many protestors were arrested across the country. In the midst of what the government defined as anarchy and subversive acts, multiple social and cultural assumptions were overturned and, in Deleuze and Guattari's terms, events and behaviours were deterritiorialized. Transient actions in established spaces smoothed the striated spaces of government planning and, equally significantly, a radical and momentary reconceptualisation of gendered roles and spaces was established.

\section{Overturning gender politics:}

Involving such critical issues as democracy, state control and police brutality, the Gezi Park protests are open to interpretation and analysis on many levels, ranging from the economic and the political, to the cultural and the social. Despite being tightly connected on almost all these levels, gender has been a conspicuously rare topic in the discourse on the resistance to date. However, among the few articles and think-pieces that explicitly address gender, two principle themes have emerged: the large number of women protesters who joined the resistance; and the masculinity of the state discourse in countering the movement.

The high proportion of women participants was not only striking at Gezi, but at all other participating sites as well. ${ }^{4}$ Although the male-female ratio was seemingly comparable to other unrelated demonstrations, such as those on animal rights or the right to abortion, the nature of female participation was arguably significantly different in this instance. This is a point made most notably, journalist Mustafa Alp Dağıstanlı, who claims that diversity amongst women in general is almost always more visible than diversity among men in Turkey - variations in female clothing that range from shorts and mini-skirts, to conservative suits and headscarfs being the most obvious reason. In the specific context of Gezi, he points out that the presence of women enabled a particularly 'striking display of diversity'. He contends that, as demonstrated by dress amongst other things, there were women from multiple backgrounds and political and religious convictions in the movement - and that this contributed to the recognition of difference in a way that marks it as unusual.

This is a particularly significant observation for two reasons. Firstly, very soon after its inception, the movement became one campaining against the government's totalizing policies in their broadest sense; and secondly, the insistent categorization of the protesters as an 'homogenous group of vandals' by the government was an obvious attempt to minimise the show of diversity the protests represented. However, just as the political elite refused to recognize any categorical difference between the protesters - whether gender, class or ethnicity - women refused to cover over their own differences while simultaneously claiming agency in the political arena. 
The Gezi resistance was a rare instance whereby women's refusal to deny the differences between them not only weakened the 'othering discourse' of the government, but also enabled the unification of the protesters - without sacrificing their diverse subjectivities. Indeed, the 'othering discourse' of the government, headlined obviously by the Prime Minister himself, was a direct manifestation of an authoritarian and paternalistic style of governance that was challenged by the wall graffiti, slogans and the more formal arguments that characterised the resistance from its early stages. Author Fatih Doğan claims that historically, the state-society relationship in Turkey has been analogous to the nuclear family structure, whereby the state functions as 'a masculine apparatus that governs the mother-land and treats the population as adolescents who need to be shown right from wrong' ${ }^{6}$

This outline position was developed in a more extensive gendered analysis by the US based academics, Zeynep Kurtuluş Korkman and Salih Can Açıksöz. ${ }^{7}$ In their analysis of the scenario, contemporary Turkish politics is an explicitly patriarchal arena of authority, hierarchy and control. Within that context, they characterize the Prime Minister's political persona as 'an innovative synthesis of Islamist and tough urban styles.' According to this reading, it was a style that prevented him from acknowledging the agency of the protestors of the Gezi Resistance. However, expanding their analysis, Korkman and Açıkgöz identify that the language of the protestors also adopted the imperatives of hegemonic masculinity on occasion - they cite examples of phallic swear words derived from the language of the poor male youth, which targeted both the Prime Minister and the police. A masculine language of resistance obviously marginalizes women, members of the LGBT community, and sex workers - all of whom actively participated in the movement. In response to this, these groups sought to transform masculine language in creative ways - sometimes by warning about its use, and sometimes by pointing to alternative non-sexist possibilities. As a result, Korkman and Açıköz conclude that the Gezi resistance transformed the everyday experience of the male-dominated public sphere for both women and members of the LGBT community through constituting and reconstituting public spaces and behaviours dynamically.

\section{Deterritorialization and spatialisation:}

Deterritorialization is, for Gilles Deleuze and Felix Guattari, a term that signifies undoing established structures and decoding systems that organize our bodies, identities, and words. ${ }^{8}$ It is tied to their notion of nomadism denoting a mode of existence that is irreducible to the dictates of the state apparatus - that are based on the fixity of language and laws. Following them, feminist scholar Rosi Braidotti explains:

The nomad does not stand for homelessness, or compulsive displacement; it is rather a figuration for the kind of subject who has relinquished all idea, desire, or nostalgia for fixity. This figuration expresses the desire for an identity made of transitions, successive shifts, and coordinated changes, without and against an essential unity. ${ }^{9}$

Notions of deterritorialization and the nomad help to explain not only the identification of protesting subjects, but also the spatial practices that were evidenced during the Gezi movement. Indeed, space emerges as a central category, both physically and metaphorically. First of all, the movement derives its name from the very location of its origin - a name that did not change in protests in other cities. Indeed, the slogan "Everywhere is Gezi; Everywhere is resistance" was chanted on the streets and circulated in print and social media in all participating locations. 'Gezi resistance,' 'Gezi movement,' and 'Gezi events' became the shorthand for newspaper headlines and media broadcasts which refered 
to similar protests in any part of the country. Hence the term Gezi, which aptly means 'promenade' in Turkish, no longer referred to a specific place in Taksim. In the public imagination, the term Gezi transcended the limited space of an urban park and took on a nomadic signification; a fluid notion that signified other spaces and other meanings.

This deterritorialization however, was not restricted to a question of synonyms for place naming and associations, it involved the overturning of the accepted gender uses and cultural definitions of space that have been at the heart of gender attitudes in Turkey for centuries. Urban spaces have historically been areas of contest produced by power relations that are often manifested in public space by means of monumental architectural gestures. In The Production of Space, Henri Lefebvre distinguishes between the modes of production of things in space and the modes of production of space itself:

The production of things was fostered by capitalism and controlled by the bourgeoisie and its political creation, the state. The production of space brings other things in this train, among them the withering-away of the private ownership of space, and, simultaneously, of the political state that dominates spaces. ${ }^{10}$

During the Gezi movement - which began as a protest against a 'mode of production of things in space,' i.e., the erection of a building in a public park - the production of space involved spatial practices which re-claimed the space of the state through deterritorializing tactics. In the process, the protestors produced unprecedented spaces which challenged fixed uses of conventional urban spaces on the one hand, and territorial boundaries of the private and the public on the other. Their urban imaginary far exceeded the limitations of the symbolic spaces of administrators and planners. Again, it reminds us of Deleuze and Guatarri who explain the relationship between the striated space of the state and the smooth space of the nomad as follows:

What interests us in operations of striation and smoothing are precisely the passages or combinations: how the forces at work within space continually striate it, and how in the course of its striation it develops other forces and emits new smooth spaces. Even the most striated city gives rise to smooth spaces: to live in the city as a nomad, or as a cave dweller. Movements, speed and slowness, are sometimes enough to reconstruct a smooth space. Of course, smooth spaces are not in themselves liberatory but the struggle is changed or displaced in them, and life reconstitutes its stakes, confronts new obstacles, invents new spaces, switches adversaries. ${ }^{11}$

At Gezi, the numerous reuses of spaces by protestors, the crossing of boundaries in terms of actions and their relationships with space and the fluidity of symbolic spatial associations, all recall these ideas in fruitful and insightful ways.

\section{Spaces of Neighbourliness:}

The multiple examples of what Deleuze and Guattari would call striation and smoothing through the creative reuse of spaces evident at the Gezi movement were prompted, ironically, by the literal violence of the police. Despite the passive resistance of the protesters, police violence was an everyday occurance throughout the period of the Gezi resistance. In Istanbul, besides the occupation of Gezi Park by protesters who pitched tents and camped-out on the site, people from other neighbourhoods gathered in Taksim square every evening to support the movement. This became such a routine act 
that special police vehicles equipped with pepper spray and water cannons were on guard daily at strategic points in the square - ready to take action whenever the crowd seemed to be reaching a critical size.

Upon police intervention, protesters dispersed to side streets in attempts to escape water cannons, the burning effects of tear gas and blows from police batons which were liberally used in defiance of basic considerations of the right to protest. Inevitably, many people were injured and help came, unexpectedly, from the residential blocks lining the labyrinthine side streets which served as escape routes. Many local residents stocked their apartment entrances with water, food, and emergency medical supplies such as lemon and talcid - which are known to sooth eye and skin irritations caused by pepper spray. Very early on an unwritten contract was established between the residents and the protesters whereby the latter knew where to get emergency relief when injured. Critical scholarship has long pointed to the historical association of masculinity with the public space of action and femininity with the inactive sphere of domesticity. ${ }^{12}$ However, what these events revealed was a marked - and remarkable in the Turkish context - instance whereby the stereotypical nurturing maternal space of the domestic interior creatively intersected with, and supported, the public space of political action.

\section{Spaces of Motherhood:}

The association of motherhood with domestic spaces is arguably the most obvious example for gendered spatial norms in general terms - and was certainly the discourse peddled by the government. During one of the public debates associated with the Gezi events, it was a position strikingly, and subversivley, described for the Prime Minister by the popular Turkish actress, Hülya Avşar. She described it with the following phrase: "The child breaks, the mother mends, the father looks the other way. This is what goes on in successful families". ${ }^{13}$ The significance of the 'lesson' came from the fact that the family analogy had long governed the Prime Minister's discourse. As Korkman and Açıköz explain:

He [Recep Tayyip Erdoğan] repeatedly recommended that the women of Turkey have three children, recently supported a prohibition on the retail sale of alcohol after $10 \mathrm{pm}$. and, in another attempt to delegitimize the resistance movement, commented on the fact that girls were sitting on men's laps in Gezi Park. Put differently, he enacts the role of a husband who wants three kids, a father who forbids drinking at night, a brother who snitches on his sister for socializing with men. He is a man who dominates, forbids, orders, scolds, degrades, and threatens. $^{14}$

Seen in this light, Avşar's statement can be read as a preamble to the call for families to help in evacuating Gezi Park made by the Governor of Istanbul, Hüseyin Avni Mutlu. On June $11^{\text {th }}$, the Governor stated that the 'innocence of the early stages of the protests had been replaced by life threatening acts by marginal groups' and made the following call, "We are concerned about our children in Gezi Park, which is has turned into an area of fire. I plead with our precious children to leave, and especially call on their families to persuade them to leave the area." ${ }^{\prime 15}$ In making this statement he clearly called for the reterritorialization of the home as the safe haven of domesticity and security and counter-positioned it with the public zone of war and violence. 
In reaction to these conservative reminders of the traditional family role, many of the mothers of the Gezi protesters actually did the opposite - they extended the domestic realm outwards to support the movement rather than closing it in. Most strikingly, two days after the Governor's call, they organized a symbolic act of support for their children in the park itself. Holding hands, they formed a circle around the park chanting 'everywhere is mother[hood], everywhere is resistance.' Rather than fulfilling their maternal function by calling their children to the safety of their homes, as the Governor's discourse suggest they do, they literally formed a wall with their bodies to house their children at the very site of resistance. In doing so, they powerfully displaced the association of motherhood with conventional conceptions of domesticity and deterritorialized the notion of home. It was another subversive response to the use of space that was a direct result of violence, but it also represented a shift in the established gendered roles of space that hints at the broader implication of these events.

\section{Spaces of Domesticity:}

Practices of deterritorialization were an unmistakable part of the Gezi movement and were not only evident on the streets and in the parks and squares, but also in the privacy of the home - often becoming a form of festive deterritorialization of the public realm. Writing about the bourgeois apartment, Henri Lefebvre relates domesticity and festivity by means of the flow of corporeality from the interior to the exterior in a way directly relevant to instances at Gezi. Lefebvre writes:

In designing a façade and its ornamentation the architect helps animate the street and contributes to the creation of urban space [...] As for the bodily 'functions' of eating and drinking, sleeping and making love, these are thrust out of sight [...] Heavy curtains allow inside to be isolated from outside, the balcony to be separated from the drawing-room, and hence, for 'intimacy' to be preserved and signified. Occasionally a curtain is drawn, and light bathes the facade: festivity is thus announced. ${ }^{16}$

One memorable example of political protest at Gezi that took the form of the festivity described here by Lefebvre, came in the first weeks of the protests. On consecutive evenings, at exactly 9:00 pm, neighbourhoods in many of the protesting cities saw flickering lights through open apartment windows as residents stepped out on their balconies holding pots and pans in their hands. Within a few minutes, the flickering lights were accompanied by the rhythmical pounding of kitchen equipment as residents turned their neighborhoods into spectacles of light and sound. Pots and pans, associated with the 'bodily functions of eating and drinking, women, and domesticity', were brought out from kitchen cupboards and taken into the masculine space of political protest. It was an act joyously carried out for exactly fifteen minutes and not only functioned as a playful act of protest but helped form bonds between neighbours around a political issue.

In one instance, this spectacular sight was 'recited' in the public space of an open-air classical concert, as internationally renowned Turkish pianist Fazıl Say preceded his scheduled performance with the pounding sound of pots and pans. ${ }^{17}$ As the audience cheered, the private space of the kitchen, the public space of the theater, and the sphere of political protest were all intertwined in an unprecedented way in modern Turkey. The consistency and spread of such a seemingly innocent acts was perceived to be so threatening that the government defined it as public offence punishable in court. ${ }^{18}$ 


\section{Spaces of Collectivity:}

In concert with his arguments on the domestic and the festive Lefebvre writes about spatial principles stemming from the 'dominance of the male principle, with its violence and love of warfare', stating that "this principle has in turn been reinforced by supposedly manly virtues, as promoted by the norms inherent to a dominated and dominating space." ${ }^{19}$ Indeed, continual exertion of police violence on the passive resistance of Gezi protesters was an embarrassingly obvious manifestation of the masculinity that dominates the public sphere under the guise of social order in Turkey, and more generally. It is a tendency and notion that lay at the heart of what was presented in the press as the 'scandal' in the Bezmialem Valide Sultan Mosque

On the fourth day of the protests, following a violent police intervention, protesters seeking escape fled inside the mosque. Joined shortly afterwards by volunteer doctors and health workers, the prayer hall was momentarily turned into a health centre in which the injured were laid on the floor and were provided with emergency care. Two days later, the event was broadcasted as a scandal by mainstream Turkish newspapers which ran stories about 'unacceptable and immoral behaviour in the mosque', including the consumption of alcohol, the smoking of tobacco, and the wearing of shoes in a holy place. Although all of these claims were contradicted by the mosque official on duty at the time, the discourse of blame continued in speeches by the Prime Minister and his fellow government officials. Interestingly however, they never mentioned the morally unquestionable first aid provision delivered in the mosque which, as the example of Ottoman mosques complexes that historically often included health care units (darüşsifa) illustrate, are totally compatible with the holy spaces of Islam. As this selective attention to 'immoral' acts clearly reveals, the criticism was calculated to undermine the protests and reinforce the government reading of them as degenerate.

However, these statements were not only a calculated attack on the protests, they easily fitted into a larger government discourse. The Prime Minister's criticism that the protesters engaged in 'all kinds of immoral activities' [in the Mosque] echoed with previous statements - which were given greater credence given the culturally polemic mixing of men and women in the main hall of the Bezmialem Valide Sultan Mosque. ${ }^{20}$ Islamic codes prohibit women and men mixing during prayer sessions on moral grounds. During prayer rows of men perform the namaz ritual - the simultaneous rhythmical acts of standing, bowing, and kneeling - while women are encouraged to perform their religious rituals at home. If they choose to go to the Mosque however, they are allocated a special space beyond the male gaze which they can only enter wearing appropriately conservative outfits, including headscarves.

The application of such codes, and their underlying principles, is a repeated theme of the government and, only a few days before the Bezmialem Valide Sultan Mosque events, the Prime Minister had commented publically on alcohol, morality and sex - specifcially in the context of behavior evident in public subway cars. The subway administration of Istanbul had earlier in the year began a series of public broadcasts in the subway which warned against immoral behaviour, specifically with regard to public displays of intimacy between sexes. To counter criticisms against the propriety of such announcements, the Prime Minister explained that "there are moral codes of behaviour in the State Subway System" and, as a result, asked "what is wrong with broadcasting warnings if these [codes] are abridged?" In his discourse he also gave an example of groups that enter the subway with alcohol and 'similar stuff' and again asked "would a mother and father want their daughter to sit on somebody's lap?" 21 He went on to say that, personally, he would have no respect for women and men who sat side by side on public seats. 
During its use as an emergency health care centre, the traditional order of the mosque space was radically transformed in ways that clearly overturned the norms set out by the Prime Minister and his government. Firstly, men and women worked in collaboration in the main hall to take care of the injured, regardless of their gender and, secondly, women were dressed inappropriately - in part because entrance into the mosque had not been preplanned and in the circumstances they had not had time to take off their shoes. As a result, the striated male space of the prayer hall was transformed as both genders performed the 'feminine role' of nurture and care. In short, a different spatial and behavioural order was established due to the requirements imposed by an emergency situation which, paradoxically, did not contradict the religiosity of the space at all.

\section{Conclusion:}

The Gezi movement marked a threshold in Turkey's recent history on a number of levels. Politically, it marked a radical challenge to the hierarchically structured, centralized governmental style of the ruling party. Psychologically, many claimed that a threshold of fear was crossed, as protesters continued their demonstrations despite increasing police brutality and governmental threats. Socially, the so-called Y-generation, which formed the majority of the protesters, showed that they were not nearly as politically apathetic and ignorant as their highly politicized parents thought. ${ }^{22}$ Culturally, it was the first time in the recent history of protests when differences in gender, class and ethnicity were collectively affirmed, and the first time that actually they strengthened a political movement rather than fragmented it. Women participated as women, mothers participated as mothers, and members of the LGBT community fully voiced their sexual identity.

In addition to these culturally specific issues in the Turkish context, it is suggested here that the events at Gezi also ruptured the striated spaces of the state apparatus by subverting established public/private boundaries and their gendered associations. The Gezi movement deterritorialized gendered significations of space and showed that masculine attributes are not inherent to public space. At the same time, they illustrated how radically democratic public spaces can be constructed by mobilizing different genders. These events did not position the feminine against the masculine, but showed how articulations of different genders and sexualities with different subjectivities can produce alternative and liberating spatial practices; a sentiment encapsulated by a phrase that was often repeated during, and in the immediate aftermath of the protests: 'nothing will ever be the same again'.

This phrase not only had literal meaning in the context of contemporary Turkish politics, it also has metaphorical meaning in the context of the ideas referenced throughout this paper. The events at Gezi could be interpreted as announcing the end of the hitherto unchallenged sedentary and striated spaces of state mechanisms, at least in Turkey. However, beyond this, they also involved a celebration of contingency. They brought the power of fluid articulations of gender and space - which were mostly unprecedented, sometimes joyful and often celebratory - to the surface. They were momentary actions always performed in recognition of their own contingency and, as such, they were premised on the idea of change - a characteristic that lends them to challenging the spatial, political and cultural status quo. 


\begin{abstract}
${ }^{1}$ According to these plans, vehicular traffic would be directed underground; facades of the surrounding buildings would be restored according to their original state; and most significantly the 19th century Ottoman barracks, which had been demolished in 1940, would be rebuilt to house a shopping mall. See: "İşte Erdoğan'1n Taksim projesi” [Here is Erdoğan's Taksim project], Hürriyet, accessed July 25, 2013, http://www.bigpara.com/haber-detay/gundem/iste-erdoganin-taksimprojesi/758227/?bprtme $=0646840528 \&$ sTo $=0$

${ }^{2}$ The site has historical associations reaching back eigthy years to the 1936 master plan of the French planner Henri Prost. See: Cana F. Bilsel, (2010). "Espaces libres: Parks, promenades, public squares," in From the Imperial Capital to the Republican Modern City: Henri Prost's Planning of İstanbul (1936-1951), edited M. Baha Tanman (İstanbul: İstanbul Araştırmaları
\end{abstract} Enstitüsü, 2010), 349-374.

${ }^{3}$ Although during its lifetime the site has seen numerous transformations, both in size and content, it remains symbolically important and one of the few recreation areas in the central area of Istanbul, which can otherwise be characterised as a site of concrete blocks of hotels, offices and apartments.

${ }^{4}$ According to a survey carried out by a professional research company (KONDA) $50.9 \%$ of the protesters were women. Emre Kongar and Aykut Küçükkaya, Gezi direnişi [Gezi Resistance] (İstanbul: Cumhuriyet Kitapları, 2013), 32.

${ }^{5}$ Mustafa Alp Dağıstanlı, “Dişi direniş” [Feminine resistance], accessed June 25, 2013, http://birdirbir.org/disi-direnis/.

${ }^{6}$ Fatih Doğan, "Devletin babalıkla imtihanı: Gezi direnişi” [The State tested agaisnt fatherhood: Gezi Resistance], accessed July 27, 2013, http://www.birikimdergisi.com/birikim/makale.aspx?mid=980\&makale=Devletin Babalıkla İmtihanı: Gezi Direnişi.

${ }^{7}$ Zeynep Kurtuluş Korkman and Salih Can Açıksöz, "Erdoğan's masculinity and the language of the Gezi Resistance,” accessed June 22, 2013, http://www.jadaliyya.com/pages/index/12367/erdogan's-masculinity-and-the-language-of-the-gezi.

${ }^{8}$ Gilles Deleuze and Felix Guattari, A Thousand Plateaus, trans., B. Massumi (Minneapolis: Univ. of Minnesota Press, 1987).

Deterritorialization is a critical term that is used in different contexts throughout the book.

${ }^{9}$ Rosi Braidotti, Nomadic subjects (New York: Columbia University Press, 1994), 22.

${ }^{10}$ Henri Lefebvre, The Production of Space trans., D. Nicholson-Smith (Oxford: Blackwell, 1991), 410.

${ }^{11}$ Gilles Deleuze and Felix Guattari, A Thousand Plateaus, trans., B. Massumi (Minneapolis: Univ. of Minnesota Press, 1987), 500 .

${ }^{12}$ Richard Sennett, Flesh and Stone: The Body and the City in Western Civilization (New York: W.W.Norton, 1994) and Mark Wigley, "Untitled: The House of Gender," in Sexuality and Space, ed. Beatriz Colomina (New York: Princeton Architectural Press, 1992), 327-389.

${ }^{13}$ Internet Haber. "Hülya Avşar Erdoğan ile görüştü” [Hülya Avşar met Erdoğan]. Accessed July 31, 2013. http://www.internethaber.com/hulya-avsar,-erdogan-ile-gorustu-547134h.htm

${ }^{14}$ Zeynep Kurtuluş Korkman and Salih Can Açıksöz, “Erdoğan's masculinity and the language of the Gezi Resistance,” accessed June 22, 2013, http://www.jadaliyya.com/pages/index/12367/erdogan's-masculinity-and-the-language-of-the-gezi.

${ }^{15}$ Bianet. "Mutlu: Gezidekilerin can güvenliği yok" [Mutlu:Those at Gezi do not have life security. Accessed July 31, 2013. http://bianet.org/bianet/insan-haklari/147482-mutlu-gezi-dekilerin-can-guvenligi-yok.

${ }^{16}$ Henri Lefebvre, The Production of Space, trans. D. Nicholson-Smith (Oxford: Blackwell, 1991), 315.

17 June 4, 2013, Bostanlı Suat Taşer Open Air Theater, İzmir.

${ }^{18}$ BBC Türkçe, "Erdoğan: Tencere, tava çalanlar yargıya taşınmalı" [Erdoğan: Those who pound pots and pans should be taken to court], accessed July 22, 2013, http://www.bbc.co.uk/turkce/haberler/2013/07/130721 erdogan gezi.shtml.

${ }^{19}$ Henri Lefebvre, The Production of Space, trans. D. Nicholson-Smith (Oxford: Blackwell, 1991), 409. 
${ }^{20}$ Gazeteport, "Dolmabahçe Camii'nde ahlaki olmayan şey yapıyorlar" [They conduct unethical things in Dolmabahçe Mosque], accessed August 15, 2013, http://www.gazeteport.com.tr/haber/136205/dolmabahce-camii nde-ahlaki-olmayan-sey-yapiyorlar.

${ }^{21}$ Sözcü, "Erdoğan: Erkek kız aynı bankta oturursa” [Erdoğan: If boy and girl share a bench], accessed August 16, 2013, http://sozcu.com.tr/2013/gundem/erdogan-erkek-kiz-ayni-bankta-oturursa.html.

${ }^{22}$ According to KONDA, the age average of the protesters was 28. Emre Kongar and Aykut Küçükkaya, Gezi direnişi [Gezi Resistance] (İstanbul: Cumhuriyet Kitapları, 2013), 32 


\section{BIBLIOGRAPHY}

BBC Türkçe. "Erdoğan: Tencere, tava çalanlar yargıya taşınmalı” [Erdoğan: Those who pound pots and pans should be taken to court]. Accessed July 22, 2013. http://www.bbc.co.uk/turkce/haberler/2013/07/130721 erdogan gezi.shtml.

http://www.bbc.co.uk/turkce/haberler/2013/06/130618_duranadam_kim.shtml

Bianet. "Mutlu: Gezidekilerin can güvenliği yok" [Mutlu:Those at Gezi do not have life security.

Accessed July 31, 2013. http://bianet.org/bianet/insan-haklari/147482-mutlu-gezi-dekilerin-canguvenligi-yok.

Bilsel, F. Cana (2010). “Espaces libres: Parks, promenades, public squares.” In From the Imperial Capital to the Republican Modern City: Henri Prost's Planning of İstanbul (1936-1951), edited by M. Baha Tanman, 349-374.. İstanbul: İstanbul Araştırmaları Enstitüsü, 2010.

Braidotti, Rosi. Nomadic subjects. New York: Columbia University Press, 1994.

Dağıstanl1, Mustafa Alp “Dişi direniş” [Feminine resistance]. Accessed June 25, 2013. http://birdirbir.org/disi-direnis/

Deleuze, Gilles and Guattari, Felix. A Thousand Plateaus, trans., B. Massumi. Minneapolis: Univ. of Minnesota Press, 1987.

Doğan, Fatih. "Devletin babalıkla imtihanı: Gezi direnişi” [The State tested agaisnt fatherhood: Gezi Resistance]. Accessed July 27, 2013.

http://www.birikimdergisi.com/birikim/makale.aspx?mid=980\&makale=Devletin Babalıkla İmtihanı: Gezi Direnişi

Gazeteport. "Dolmabahçe Camii'nde ahlaki olmayan şey yapıyorlar" [They conduct unethical things in Dolmabahçe Mosque]. Accessed August 15, 2013. http://www.gazeteport.com.tr/haber/136205/dolmabahce-camii_nde-ahlaki-olmayan-sey-yapiyorlar Hürriyet.” İşte Erdoğan'ın Taksim projesi” [Here is Erdoğan's Taksim project]. Accessed July 25, 2013. http://www.bigpara.com/haber-detay/gundem/iste-erdoganin-taksimprojesi $/ 758227 /$ ?bprtme $=0646840528 \& \mathrm{sTo}=0$

Internet Haber. "Hülya Avşar Erdoğan ile görüştü” [Hülya Avşar met Erdoğan]. Accessed July 31, 2013. http://www.internethaber.com/hulya-avsar,-erdogan-ile-gorustu-547134h.htm

Kongar, Emre and Küçükkaya, Aykut. Gezi direnişi [Gezi Resistance]. İstanbul: Cumhuriyet Kitapları, 2013.

Korkman, Zeynep Kurtuluş and Açıksöz, Salih Can. “Erdoğan's masculinity and the language of the Gezi Resistance.” Accessed June 22, 2013. http://www.jadaliyya.com/pages/index/12367/erdogan'smasculinity-and-the-language-of-the-gezi 
Lefebvre, Henri. The Production of Space trans., D. Nicholson-Smith. Oxford: Blackwell, 1991.

Sözcü. "Erdoğan: Erkek kız aynı bankta oturursa" [Erdoğan: If boy and girl share a bench]. Accessed August 16, 2013. http://sozcu.com.tr/2013/gundem/erdogan-erkek-kiz-ayni-bankta-oturursa.html 